\title{
HORTICULTURE IN ANTIQUITY, WITH EMPHASIS ON THE GRAECO-ROMAN ERA
}

\author{
L Cilliers \& F P Retief (University of the Free State, Bloemfontein)
}

The evolution of horticulture (gardening) in antiquity, as distinct from largescale agriculture and forestry, is traced from its humble origins in ancient Egypt and Mesopotamia, to the Graeco-Roman era. Little is known about horticulture in the Greek Bronze Age and Homeric period, but from the $5^{\text {th }}$ century onwards, public rather than private gardens became popular. In Athens a market garden was planted on the agora, and public parks (containing trees without flowers or decorative shrubs) like the Academy and Lyceum, appeared on the outskirts of the cities. Orchards and vegetable gardens were usually placed outside city walls and domestic gardening in and around homes were virtually unknown. The Greeks used wild flowers rather than cultivated flowers. Graveyards were planted with trees, and sacred groves, often in idyllic settings, were associated with shrines and divinity. During the Hellenistic era, exotic gardens based on the Persian paradeisos, were introduced by the affluent. The Romans made extensive use of private and domestic horticulture. In their homes (domus) built on the Greek model, the peristyle in particular, was converted into a garden containing trees, shrubs, flowers and vegetables. Further walled gardens were often attached to the domus. In large cities where the majority of citizens lived in multi-storied apartments (cenaculae), domestic gardening was restricted to occasional climbing plants and potted flowers decorating pillars, balconies and window sills. Wealthy Romans erected villas on country estates where indoor gardens and outside horticultural projects often included large orchards, gardens and vegetables shrubs and flowers, as well as tree-lined walking lanes, shrines, statues and water features. Facilities for horse riding were common, as well as pleasure gardens on the paradeisos model.

\section{Introduction}

Gardening and a respect for nature, often associated with supernatural beings and divine forces, go back to the dawn of civilization. Garden myths from the Middle East must be the earliest recorded manifestations of this culture; of these the Babylonian story of Gilgamesh ( $2^{\text {nd }}$ millennium BC) and its sacred wood is best known. The Greek gods on Mount Olympus lived in sacred groves around caves, springs and streams. The Biblical creation story also terminates in the establishment of a Garden of Eden, dwelling place of the first human beings.

This study covers the evolution of horticulture (the art of the cultivation of a garden) in the Mediterranean area of antiquity, and the Graeco-Roman era in particular. Hortus, Latin for "garden", was used for all sizes of garden. Horticulture is distinguished from agriculture (agronomy, large-scale soil management in order to raise crops) and the discipline of forestry. 
Pre-Classical era

Egypt

In antiquity Egypt's economy was based on large-scale gardening and crop raising in the alluvial soil deposited by annual flooding of the Nile. This should be classified as agriculture, not horticulture, but there is also limited evidence on wall paintings of personal gardens at homes of the wealthy, showing gardeners tilling flowers, shrubs and trees, often associated with pools. Palaces and temples sported gardens, and the temple tomb of Queen Hatshepsut had a prominent garden. It is very probable that the Assyrians and Greeks acquired their subsequent interest in horticulture from these Egyptian gardens (Farrar 1998:1-3).

\section{Mesopotamia}

The ancient civilization of Sumer, between the Tigris and Euphrates, made use of irrigation from these rivers to plant gardens. In addition to large-scale agriculture there is also evidence of the planting of shady trees, and small vegetable gardens. No visual depictions of this have survived though.

The Assyrians $\left(10^{\text {th }}\right.$ to $7^{\text {th }}$ centuries BC) left documentary evidence of the planting of trees, and on relief sculptures pictures of gardens and probable fruit trees appear; one illustration seems to depict the manual pollination of fruit tree flowers. The nobility showed great interest in trees, for palace gardens in particular. Trees were even listed as items of plunder after warring raids. Senacherib brought trees from the Hittite country (Turkey), Tiglath Pileser mentioned conquered trees, and Ashurbanipal showed a special interest in botanical specimens of fruit trees and scented shrubs.

Babylon under Nebuchadnezar (604-562 BC) constructed its famous Hanging Gardens, one of the Seven Wonders of Antiquity. It almost certainly consisted of extensive gardening on the terraces of stepped ziggurats, watered by means of screw pumps (Farrar 1998:3-5; Diodorus Siculus 2.10).

From the $6^{\text {th }}$ century BC onwards the Persians planted large luxurious parks which so impressed the Greeks that the indigenous name, paradeisos, was taken over as the origin of the word, paradise (Farrar1998:9-10). These walled parks were often large enough to accommodate wild animals for hunting purposes; others were smaller and contained flowers (Xenophon commented on the sweet aromas, Oec. 4.21), orchards, vegetable plots and gardens with trees only (Olck 1910:769-770).

\section{Greece}

\section{Early Greece}

Little is known about gardening in the Greek Bronze Age (Minoan and Mycenaean cultures), but engravings show evidence of sacred trees, usually associated with shrines. Palace frescoes depict floral motives, especially of crocus and lily but also 
Egyptian Nile plants. These appear to depict landscape scenes rather than gardens, although there is some evidence of potted flowers at Knossos. There is no clear indication of gardens in homes. Cypress trees were apparently imported from Semitic countries (Farrar 1998:4-5).

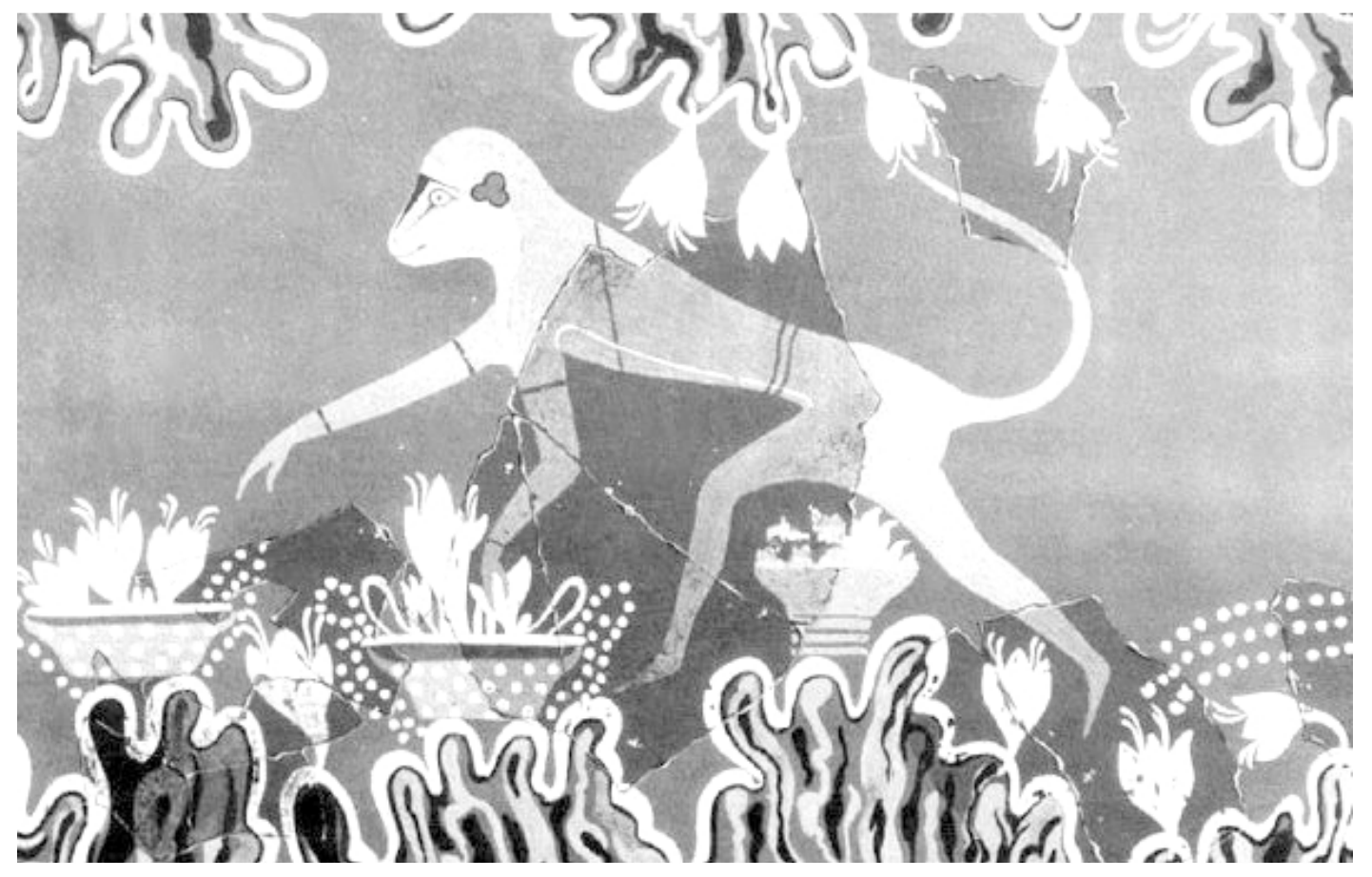

Fig. 1: Detail from the Saffron gatherer wall painting at the palace of Minos, Knossos, c. 1550 BC.

During the Greek Dark Ages (1200 - 800 BC) there is evidence of increasing but still limited gardening in the fortified cities. Produce was mainly cultivated outside city walls, and orchards, vines, herbs and vegetables were preferred to flowers. However, a few local varieties of flowers and roses in particular, did become popular. The wild rose was cultivated. Grave yards were planted with trees, and planes in particular. Trees were mostly grown for their wood; date palms were introduced (Olck 1910:771-778).

Homer $\left(8^{\text {th }}\right.$ century BC) makes limited mention of rustic, walled gardens containing fruit trees in particular (Farrar 1998:5-6). In the Odyssey mention is made of pear orchards, olives, figs, pomegranates, apples and vines (24.225 ff.). The idealized garden of Alkinoös, king of the mythical Phaiacians, was essentially a walled orchard, without flowers (Od. $8.112 \mathrm{ff}$.). The father of Odysseus, Laertes, is described digging in his orchard under a pear tree (Od. 24.225 ff.). The dwelling place of the nymph, Calypso, is vividly pictured as a garden-like cave (Od. $5.55 \mathrm{ff}$.). Roses were popular and in the Iliad rose oil was used as an embalming agent (23.186 ff.). 
Classical Greece $\left(5^{\text {th }}\right.$ century BC onwards $)$

The Greeks of this era preferred public gardens to private gardens. Farrar (1998:7-8) suggests that this was probably in part due to their democratic habits which called for citizens (and men in particular) to gather regularly in public places for participation in politics and other activities of state. Cimon $\left(5^{\text {th }}\right.$ century BC) planted mainly plane trees, myrtle and laurel in his market garden on the Athenian agora. Other trees planted in Greece included the oak, poplar, cypress and spruce; fruit trees were olives, figs, apples, pears, plums, pomegranate, peaches (imported from Persia) and grape vines. Cimon also laid on a water supply to create a public park outside Athens in the valley of Kephissos. This became the famous Academy, used by philosophers like Socrates and Plato who taught and strolled in the ample shade. It was also used as a gymnasium. No flowers or ornamental shrubs were planted. In the next century Aristotle and his Peripatetic School were responsible for the creation of a similar park facility (the Lyceum) on the eastern outskirts of Athens near the Ilissus stream (Olck 1910:783-784; Farrar 1998:8; Thompson \& Griswold 1982:7, 16, 21).

Pliny ( $H N$ 19.19.51) claimed that Epicurus $c .250 \mathrm{BC}$ was the first to grow a house garden in a Greek city, but it is known that Demosthenes, $4^{\text {th }}$ century BC (Olck 1910:786-787) and his contemporary, Aristotle (DL 10.14) had house gardens. Farrar (1998:7-8) suggests that very rarely herbs and flowers might have been grown in courtyard pots, but otherwise domestic gardening was unknown. Related to it, however, was the strange cult of Adonis, based on the myth that during Venus' mourning for Adonis (killed by a wild boar), her falling tears caused short-lived anemones to sprout from the earth. This was then commemorated as a day of lamentation when quick growing flower seeds were planted in old pots and amphorae, which were then placed on roofs, where the flowers were allowed to die (Olck 1910:807-808). The Greeks used wild flowers (the rose in particular) rather than cultivated flowers, as scent in bridal chambers, and to counter odours at funerals. Trees were grown at shrines, of which the garden at the temple of Hephaistos in Athens is an example. Sacred groves were planted near springs, streams and natural caves. Aristotle recorded an interesting law which required that house refuse should be collected and prepared as fertilizer for gardens outside the city walls - no mention being made of gardens in the city (Ath. Const. c. 50). However, we know that city gardens were laid on by Theophrastus, Epicurus and Pericles. Outside Attica public gardens could be found in Pergamon, Thasos, Ephesus, Syracuse, Cos and Rhodes, where the city emblem was a rose (Olck 1910:783-787).

The typical Greek house had an entrance which opened into a roofless courtyard (peristyle) with a floor which was paved or of beaten earth. Rooms were placed around the peristyle, including a triclinium (dining room with reclining couches) and an andron (men's meeting place, Paoli 1944:79). Jashemski (1979:18-19) suggests that very occasionally the peristyle might have contained a few potted plants, but as a rule Greek homes did not include a garden. In Hellenistic times the houses became somewhat larger with porticos and verandahs surrounding the paved peristyle - this directly influenced the Samnite and Roman houses of later years (Jashemski 1979:337). 
The Hellenistic era was characterized by more exotic gardens due to Eastern influences introduced from Persia, inter alia by Xenophon and the returning armies of Alexander the Great (later $4^{\text {th }}$ century BC). The paradeisos gardens were copied by the ruling class, and appeared in royal abodes at Pergamon, Aigai, Pella and Demetria (Farrar 1998:8-9). Theophrastus (370-288 BC) who owned a garden, published his Enquiry into Plants, extending the knowledge and understanding of ornamental plants, vegetables, herbs and a limited number of cultivated flowers useful for wreaths and garlands. The plants included roses (the most popular) gilliflower, carnations, marragon lily, crocus, violet, anemone, narcissus, daisy, oleander and herbs like thyme, bergamot, fennel, rosemary, lavender, sage, origanum, basil, sweet marjoram and calamint. Nicander of Colophon ( $2^{\text {nd }}$ century BC) also contributed to plant knowledge (Olck 1910:788-803).

\section{Rome}

Pre-Empire (up to $1^{\text {st }}$ century BC)

From the earliest times Roman horticulture differed significantly from its Greek counterpart. Whereas Greek gardens tended to be public facilities, the Romans laid emphasis on private gardens. Home gardens, virtually absent in Greek society, formed an essential part of Roman horticulture (Farrar 1998:22).

\section{Roman homes and villas}

The typical Roman home (domus) was largely based on the Greek model, but was usually larger. It consisted of a more formal forward component for visitors and receptions, and an informal component for family life. A doorway (ostium) and small vestibule led into the atrium with open roof (compluvium) allowing rain water to fall onto a floor area (impluvium), from where it was channelled into subterranean cisterns. Restricted sleeping quarters (cubiculae) and a reception room / study (tablinum) were arranged around the atrium. As early as the $2^{\text {nd }}$ century $\mathrm{BC}$, an informal rear section, based on the Greek peristyle model, became part of the domus. Windows in the atrium and tablinum were designed to allow a vista on to the peristyle garden. Entering it from the atrium through the andron, the peristyle was a square open courtyard, usually surrounded by a portico or colonnade, and leading on to a triclinium (dining room with reclining couches), kitchen (culina) and multipurpose rooms (exhedra, oecus). The cramped slave quarters also led out of the peristyle, and were often on a second floor. Different to the Greeks, the peristyle contained plants. There could also be a separate walled garden further to the rear. More wealthy owners had multiple peristyles and rear gardens. The walls often contained paintings and frescoes; mosaic floors were not uncommon. Originally dependent on rainwater, the later construction of aqueducts ensured an abundant water supply to those who could afford it (Paoli 1944:80-100; Farrar 1998:15-21).

In large cities the vast majority of citizens lived not in a domus, but in multistoried mass housing with apartments (cenaculae). In $1^{\text {st }}$ century Rome, there were on average 26 insulae (city blocks with mass housing) for every private domus 
(Carcopino 2004:28). These apartment houses did not have gardens, but we are told that climbing plants and potted flowers often decorated pillars, balconies and window sills (Pliny $H N$ 19.59).

From the $2^{\text {nd }}$ century BC onwards, wealthy Romans erected stately homes (villae) on estates in the country side, but rarely in the city. The structure of villas varied considerably but was essentially of two kinds: the relatively modest villa rustica where the villarius (person in charge of farming) and his staff lived, and the elaborate villa urbana, inhabited by the owner. In the latter, the atrium was often replaced by a large peristyle connected to surrounding free standing units (e.g. triclinia, cubiculae, zothecae (libraries and studies) and extensive bath facilities based on city thermae) by a roofed passage way (cryptoporticus). Outside the villa there were usually pillared pathways for strolling (ambulationes) and for horse riding (gestationes). Internal house gardens were complemented by external vineyards, fruit, vegetable and flower gardens (horti rustici), as well as extensive farming areas and a walk planted with trees (xystus), with benches for sitting, water features, statuettes and shrines to placate the gods responsible for good crops (Paoli 1944:101-108; Farrar 1998:15-21). In literature we have records of many such villas, including that of Varro ( $1^{\text {st }}$ century BC) which included a fish pond; he was a very enthusiastic gardener, wine maker and owner of olive mills (Purcell 1983:6.5-8; Fowler 1937:260-261). Cicero (106 - 43 BC) owned at least six villas (Fowler 1937:251), and the villa of the extremely wealthy Lucullus on the Bay of Naples was famous for its beautiful gardens (Littlewood 1987:10-11).

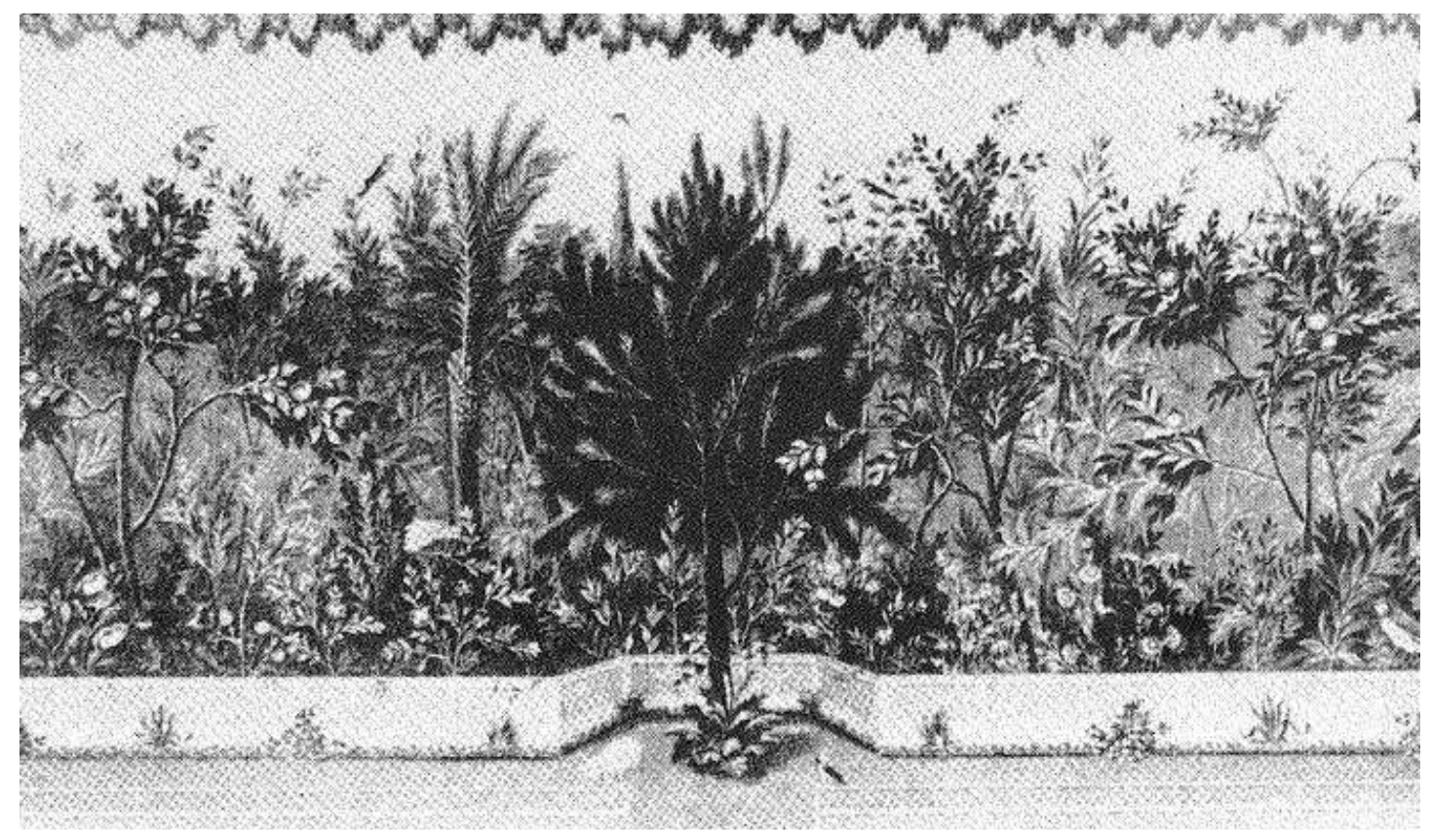

Fig. 2: Late $1^{\text {st }}$ century BC wall painting from the Garden Room, Villa of Livia, Prima Porta.

The estate of Lipinus ( $1^{\text {st }}$ century BC) included Rome's first game park (boars and roebuck), aviaries and fish ponds. Cato was the most famous early Roman author on 
gardening. In his De Agri Cultura he propagated the ancient mores of Roman society, complemented by contemporary knowledge. His enthusiasm for vegetable growing (and the wondrous properties of cabbage in particular) was surpassed only by his love of the vineyard (Cato RR 1.7; Fowler 1937:250; Farrar 1998:13, 132).

\section{Gardens}

From its early days gardens played an important role in the lives of the Roman community.

House (domus) gardens featured prominently — originally they were vegetable gardens, but in time ornamental shrub, herb and flower gardens became popular. Gardens were situated either separately (but walled and attached to the rear of the house), or inside, and then predominantly in the peristyle, commonly around a central pool. Plants were usually planted in the soil, but occasionally in containers on the porticoes or colonnade. Beds for plants were known as areae, the cultivated fields on a farm were called agri (origin of agriculture). Trees for shade were commonly planted even in small peristyles. Planes and cypress trees were popular, as well as fruit trees (e.g. vine, olives, pears, apples, figs, cherries and lemon [citron]). Shrubs, herbs and flowers were selected to ensure an evergreen effect, turning the peristyle into a veritable pleasure-garden in which the family could relax, eat or perform domestic chores, like weaving or needlework.

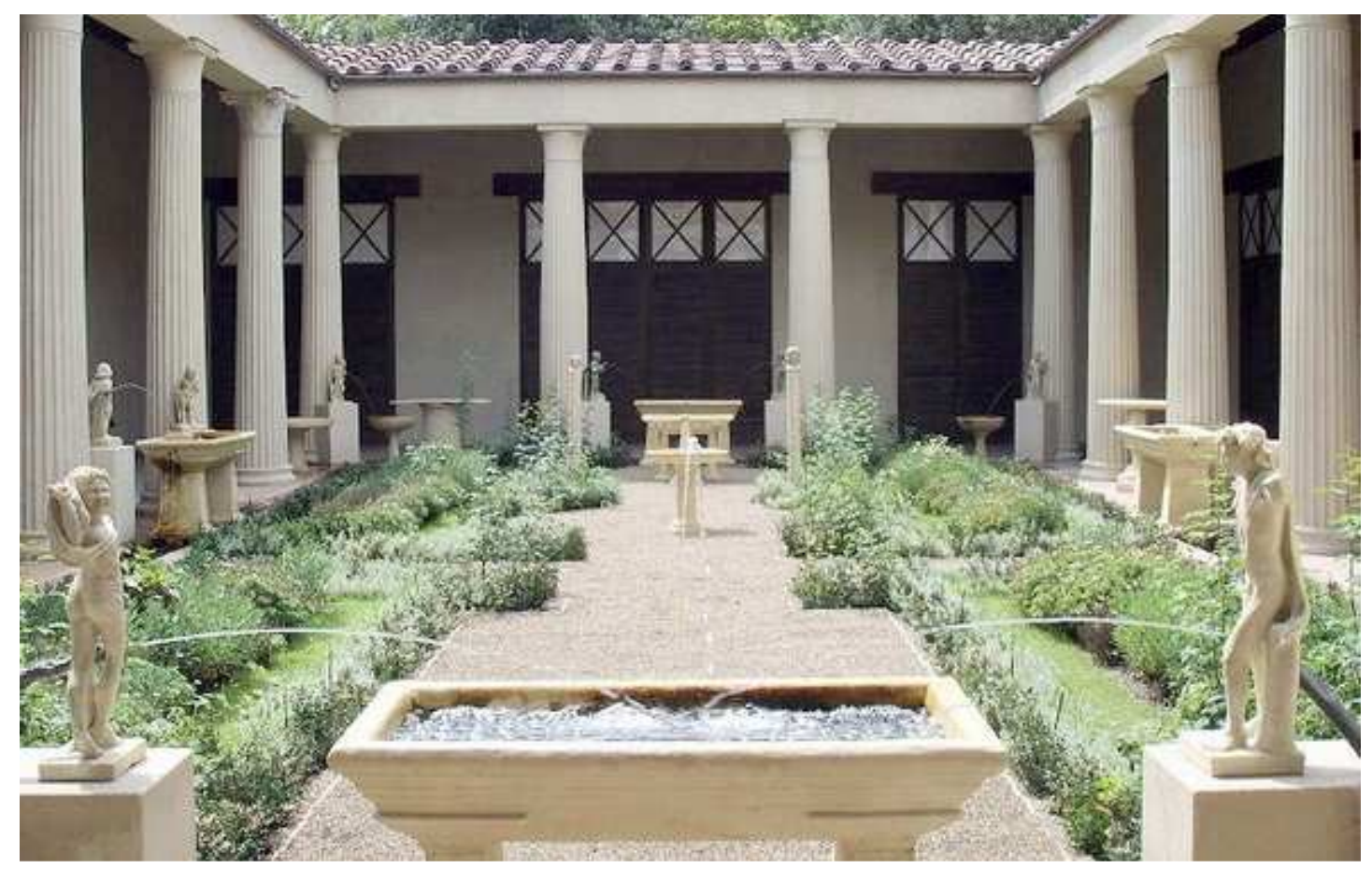

Fig. 3: Reconstruction by Sailko of the garden of the House of the Vettii, Pompeii. ${ }^{1}$

http://commons.wikimedia.org/wiki/File:Ricostruzione_del_giardino_della_casa_dei_vetii_di_ pompei_(mostra_al_giardino_di_boboli,_2007)_01.JPG 
The area could also contain tables and seats, sculptures, shrines, water features with frescoes or paintings on the walls, and decorative fencing and trellis work (Farrar 1998:12-15). Pliny is a source of extensive information on contemporary plants, also quoting from Theophrastus and Dioscorides, who concentrated on medicinal plants (Farrar 1998:130). It is estimated that by the $1^{\text {st }}$ century BC 408 plants were known (Jashemski 1987:33-34). Vegetables included asparagus, fava beans, beet, cucumber, cabbage, carrots, garlic, unions, lettuce, radish, turnip and rocket; herbs (as ornamental shrubs) included basil, caraway, rosemary, sweet marjoram, coriander, dill, fennel, lavender, laurel, thyme, mint, saffron and pepperwort. The most popular flowers (used mostly for garlands and wreaths) included roses, violets, lilies, daisies, box and oleander. Dogs, cats and domesticated birds apparently frequented the gardens (Farrar 1998:130-159). Attention was paid to effective fertilization of garden soil, and optimal irrigation depending on available water supply (Farrar 1998:166-174).

Villa gardens closely resembled domus gardens, but outside gardens in particular were usually of larger size with predominantly vegetables, vines and orchards (Jashemski 1987:33-75). This could necessitate more specialized gardeners and gardening techniques. An expert in the tending of vegetables, for instance, was known as an holitor. An arborator looked after trees (mostly orchards), a vinitor cared for vines, and a topiarius was expert in clipping hedges and looking after pleasure gardens. An aquarius was responsible for the watering of gardens. Hortulanus gradually became the all-embracing term for a gardener (Friedlaender 1920:336-340).

Ancient Roman cities were commonly surrounded by a green belt of public gardens, utilized for pleasure, profit and burial (Purcell 1983:5). Cemeteries were traditionally in gardens. The first public park in Rome was the Portico (55 BC), but gradually many public gardens, orchards and vineyards appeared within its walls. Gardens were planted at public baths, palaces, temples, and trees appeared along streets and in fora. Public eating places and inns planted their own gardens (Jashemski 1979:141-199, 338-339).

\section{Empire}

Archaeological evidence from Pompeii and Herculaneum (destroyed by the eruption of Vesuvius in 79 AD) proved most useful in understanding Roman horticulture during the early Empire (Jashemski 1979:1-5).

Gradual evolution of domus architecture and increased water supplies from aqueducts had an influence on domestic horticulture (Jashemski 1979:50). In many later homes the atrium was converted into a peristyle, with the impluvium becoming a basin or water pool surrounded by a garden, now called a viridarium. Second floor housing facilities became more popular, with balconies and verandahs, which often contained potted plants. Roof gardens appeared (Seneca Ep. 122.8; Martial 11.18). More abundant water supplies led to more extensive garden outlays, including bigger trees, more water fountains and pools. An increasing lack of housing space led to semi-peristyles with more concentrated container gardening under roofed colonnades and porticoes surrounding only half a traditional peristyle structure. Wall frescoes 
increased as did garden sculptures, pergolas and wall shrines (lararia, aediculae), conveying a more sacred atmosphere. Outdoor dining couches became a permanent fixture, with sunken or terraced gardens. Shrine-like water fountains (nymphaea) become popular (Farrar 1998:28-47; Jashemski 1979:25-54).

Purcell (1983:6) states that excesses in the construction of villa estates became a vulgar fashion. Nero's Golden House built as a fantasy palace with imitation landscapes, had a revolving dining room with its movements based on astronomical principles (Purcell 1983:7). Tiberius's villa on the Tyrrhenian coast had a magnificent garden containing an imitation of Calypso's cave, many statues and a fishpond with seawater; he invented a cold-frame for forcing cucumber growth (Purcell 1983:8). Hadrian's villa in Tivoli was famous for its garden (Friedlaender 1920:340), as was the villa of Pollius Felix in the Bay of Naples (Friedlaender 1920:338-339). Pliny had villas in Laurentium and Tuscany, the latter containing a hippodrome for horse riding (Paoli 1944:106-109). It is recorded that a beautiful villa of Vopiscus on the Anio river had a very tall tree projecting through the roof (Friedlaender 1920:339). During the $1^{\text {st }}$ century Columella wrote excellent manuals on agriculture and horticulture (Farrar 1998:xv).

The city of Rome acquired prominent gardens in open areas, which became landmark structures, for instance, those in the area beyond the Tiber, the Horti Aboniani, Horti Pompeii superioris, Horti Maecenatiani; the gardens of Drusus, Lucullus, Cassius, Lamia, Sallust, Silius, Scapulas, Galba, and Regulus were in the same category (Davis 1928:372-373; Paoli 1944:207).

Littlewood (1987:14-15) states that gardening probably remained part of Roman culture up to the $6^{\text {th }}$ century. Archaeological evidence suggests that existent literature on gardening up to the mid-second century $\mathrm{AD}$, is reliable, with little exaggeration and fantasy. Thereafter, however, the situation is less clear. Statements in the Historia Augusta, for instance should be viewed with a degree of suspicion and often with disbelief. After the $2^{\text {nd }}$ century literature on horticulture in the Roman Empire appears less objective. This study only covers horticultural history up to this time.

\section{BIBLIOGRAPHY}

Carcopino, J 2004. Daily life in Ancient Rome. London: Folio Society. Farrar, L 1998. Ancient Roman Gardens. Thrupp, Gloucestershire: Sutton Publ. Fowler, W W 1937. Social life in Rome in the time of Cicero. London: McMillan $\&$ Co.

Friedlaender, L 1920. Darstellung aus der Sittengeschichte Roms. Leipzig: S. Hirzel. Gummere, R M 1920. Seneca. Epistles. Loeb Classical Library Vol. V. Cambridge MA: Harvard University Press.

Hicks, R D (trans.) 1925. Diogenes Laertes. Lives of the eminent philosophers. Loeb Classical Library Vol. V. Cambridge MA: Harvard University Press. Jashemski, W F 1979. The Gardens of Pompeii. New York: Caratsos Bros. Publ. 
Jashemski, W F 1987. Gardens in villas at Boscoreale and Oplontis. In McDougall, E B, Ancient Roman Villa Gardens. Washington DC: Dumbarton Oaks Research Library.

Littlewood, A R 1987. Gardens from the $1^{\text {st }}$ Century BC. In McDougall, E B, Ancient Roman Villa Gardens. Washington DC: Dumbarton Oaks Research Library.

Marchant E C, Todd O J (trans.) 1923. Xenophon. Oeconomicus et al. Loeb Classical Library Vol. IV. Cambridge MA: Harvard University Press.

Olck, 1910. Paulys Realencyclopädie der Classischen Altertumswissenschaft. Wissowa, W, Kroll, J B (edd.). Stuttgart: Metzlersche Verlagsbuchhandlung.

Oldfather, C H (trans.) 1935. Diodorus Siculus. Library of History. Loeb Classical Library Vol. II. Cambridge MA: Harvard University Press.

Paoli, V E 1944. Vita Romana. Trans. J Storms. Amsterdam: N V Uitgewerÿ Lievenlu.

Purcell, N 1983. Roman Gardens. Omnibus 6.5-8.

Rackham, H (trans.) 1950. Pliny. Natural History. Loeb Classical Library Vol. V. Cambridge, MA: Harvard University Press.

Shackleton Bailey. D R (trans.) 1993. Martial. Epigrams. Loeb Classical Library Vol. III. Cambridge MA: Harvard University Press.

Thompson, B D \& Griswold, R E 1982. Garden lore of ancient Athens. Athens: American School of Classical Studies.

Van Rensburg J P J (vert.) 1952. Homerus. Ilias. Stellenbosch: Pro Ecclesia Drukkery.

Van Rensburg J P J (vert.) 1963. Homerus. Odusseia. Kaapstad: Human \& Rousseau. 